\title{
Microwave Assisted Synthesis of Novel Imidazolopyridinyl Indoles as Potent Antioxidant and Antimicrobial Agents
}

\author{
Jaiprakash S. Biradar, ${ }^{1}$ Parveen Rajesab, ${ }^{1}$ and Sasidhar B. Somappa ${ }^{1,2}$ \\ ${ }^{1}$ Central Research Lab, Department of Chemistry, Gulbarga University, Gulbarga-585 106 Karnataka State, India \\ ${ }^{2}$ Organic Chemistry Section, Chemical Sciences \& Technology Division, National Institute for Interdisciplinary Science and \\ Technology (CSIR), Thiruvananthapuram, Kerala State 695019, India
}

Correspondence should be addressed to Jaiprakash S. Biradar; jsbiradar@yahoo.com

Received 9 May 2013; Accepted 8 October 2013; Published 21 January 2014

Academic Editor: Beatriz Oliveira

Copyright (C) 2014 Jaiprakash S. Biradar et al. This is an open access article distributed under the Creative Commons Attribution License, which permits unrestricted use, distribution, and reproduction in any medium, provided the original work is properly cited.

We describe herein the design, synthesis, and pharmacological evaluation of novel series of imidazolopyridinyl indole analogues as potent antioxidants and antimicrobials. These novel compounds (3a-i) were synthesized by reacting 3,5-disubstituted-indole-2carboxylic acid (1a-i) with 2,3-diamino pyridine (2) in excellent yield. The novel products were confirmed by their IR, ${ }^{1} \mathrm{H} N M R,{ }^{13} \mathrm{C}$ NMR, mass spectral, and analytical data. These compounds were screened for their antioxidant and antimicrobial activities. Among the compounds tested, 3a-d showed the highest total antioxidant capacity, scavenging, and antimicrobial activities. Compounds $\mathbf{3 c - d}$ and $\mathbf{3 g}-\mathbf{h}$ have shown excellent ferric reducing activity.

\section{Introduction}

The continuous search for novel agents which target pathological processes of human carcinogenesis has led to the synthesis of small molecules which may modulate cell cycle [1]. Free radicals are referred to as oxidizing agents because they tend to cause other molecules to donate their electrons [2]. Reactive oxygen species (ROS) are a product of normal cellular metabolism [3]. ROS plays a vital physiological role in several intracellular signaling and regulations [4]. Antioxidants have the ability to neutralize free radicals and prevent the damage caused by them [5]. Antioxidants, even at low concentration, significantly delay or prevent the oxidation of easy oxidizable substrates [6]; when in high concentrations, ROS can damage cell structures, nucleic acids, lipids, and proteins [7]. In the normal metabolism status, the level of free radicals and antioxidants in humans is maintained in balance, which is important for sustaining optimal physiological conditions [8]. The reactive oxygen species (ROS) are implicated in numerous pathological conditions such as diabetes, liver damage [9], inflammation, aging, atherosclerosis, carcinogenesis $[10,11]$, and neurodegenerative [12] disorders like
Parkinson's, Alzheimer's, and amyotrophic lateral sclerosis (ALS) [13].

The treatment of infectious microbial disease remains a pressing problem worldwide [14, 15]. A major research emphasis to counter this growing problem is the development of antimicrobials structurally unrelated to the existing molecules. One possibility to achieve this goal is the combination of a molecule with structural elements possessing appropriate biological activities $[16,17]$. Nitrogen-bridgehead fused heterocycles containing an imidazole ring is a common structural component in pharmacologically important molecules, with activities spanning an assorted range of targets [18], such as antiviral [19] and anticancer [20-22]. Imidazolopyridine analogues are an important class of biologically active compounds showing anticancer [1], antiviral [23], analgesic [24], and anti-HIV [25] activities. Diaminopyridine analogues possess a wide range of biological activities [26] such as treatment of multiple sclerosis and [27] antiviral, rodenticidal [28], antimicrobial, and cytotoxic $[29,30]$ activities.

Besides, indoles are featured in a wide variety of biologically and pharmacologically active compounds [31]. One of 
the natural antioxidants is melatonin possessing an indole ring, which is produced in the body and acts as a free radical scavenger [32]. The indole derivatives are known to possess anticancer DNA cleavage, antioxidant [33-37], antirheumatoidal, and anti-HIV [38] activities.

The search for an innovative key for the reduction of chemical steps, wastes, short reaction time, easy workup, and increased yield in organic processes has become a thoughtprovoking task. This can be overcome by carrying out the reaction in microwave condition. Microwave irradiation is an important method which is being increasingly used to accelerate organic reactions. Several methods have been reported for the synthesis of imidazoles in the presence of catalyst and solvents such as $\mathrm{P}_{2} \mathrm{O}_{5}$ and Methanesulfonic acid [39], Alumina-Methanesulfonic acid [40], $\mathrm{HCl}$ [41], polyphosphoric acid [42], and ethylene glycol [43]. However, it was noticed that all these methods involve an assortment of drawbacks such as difficult to workup, prolonged reaction time, low yields, and use of expensive and environmentally toxic organic reagents or catalyst or solvent. We have developed an ecofriendly, efficient, less energy, and catalyst free method for the synthesis of imidazolopyridinyl indoles. Therefore, considerable interest is focused on the microwave assisted synthesis of imidazolopyridinyl indole analogues as potent antioxidants (free radical scavenging, total antioxidant capacity, and ferric reducing antioxidant power) and antimicrobial activities of pharmacologically active compounds.

\section{Experimental}

2.1. Chemistry. All chemicals used in this investigation were analytical grade and were purified whenever necessary. Melting points of the synthesized compounds are measured in open capillaries and are uncorrected. Reactions are monitored by thin-layer chromatography (TLC) on silica gel 60 $\mathrm{F}_{254}$ aluminium sheets (MERCK). Iodine vapour was used as detecting agent. IR spectra are recorded in $\mathrm{KBr}$ on Perkin Elmer and FTIR spectrophotometer $\left(\nu_{\max }\right.$ in $\left.\mathrm{cm}^{-1}\right) .{ }^{1} \mathrm{H}$ NMR and ${ }^{13} \mathrm{C}$ NMR spectra are recorded on BRUKER AVENE II $400-\mathrm{MHz}$ NMR spectrometer (chemical shift in $\delta \mathrm{ppm}$ down field from TMS as internal reference). The mass spectra are recorded on LC-MSD-Trap-SL instruments. The elemental analysis was determined on FLASH EA 1112 SERIES instrument.

2.1.1. General Procedure for the Synthesis of Compound 1a-i. The precursors 3,5-disubstituted indol-2-carboxylic acid (1ai) were obtained from 3,5-disubstituted indol-2-carboxylates by reported method [44].

\subsubsection{General Procedure for the Synthesis of Compound $\mathbf{3 a}-\boldsymbol{i}$}

Conventional Method. A mixture of 3,5-disubstituted indol2-carboxylic acid (1a-i) (0.01 mol) and 2,3-diaminopyridine $2(0.01 \mathrm{~mol})$ were refluxed $5-6 \mathrm{~h}$ in $15-20 \mathrm{~mL}$ of ethanol. The completion of reaction was monitored by TLC. After completion of the reaction, excess of solvent was removed under reduced pressure and kept at room temperature for a few hours for the formation of crystals. The product obtained was filtered and purified with ethanol. All the newly synthesized compounds were characterized by elemental analysis and IR, ${ }^{1} \mathrm{H}$ NMR, ${ }^{13} \mathrm{C}$ NMR, and mass spectroscopic data; yield was 65-75\%.

Microwave Assisted Synthesis. A mixture of 3,5-disubstituted indol-2-carboxylic acid (1a-i) $(0.01 \mathrm{~mol})$ and 2,3-diaminopyridine (2) $(0.01 \mathrm{~mol})$ were powdered, mixed, and introduced in an open borosil glass vessel containing a few drops of ethanol. This was subjected to microwave irradiation for 10 minutes with $70 \%$ microwave power. After completion (TLC), the reaction mixture was brought to room temperature, washed with aqueous ethanol, and recrystallized to get the title compound $\mathbf{3 a}-\mathbf{i}$, which was found to be in high purity (TLC) and in excellent yield (80-98\%).

(1) 2-(5-Chloro-3-phenyl-1H-indol-2-yl)-3H-imidazolo[4,5b]pyridine (3a). m.p. $251-252^{\circ} \mathrm{C}$; IR $(\mathrm{KBr}) \nu_{\max }\left(\mathrm{cm}^{-1}\right): 3449$, 3416; ${ }^{1} \mathrm{H}$ NMR (DMSO-d $6+\mathrm{CDCl}_{3}$ ) $\delta$ (ppm): 12.02 (s, $1 \mathrm{H}$, Indole $\mathrm{NH}$ ), 11.50 (s, 1H, Imidazolopyridine $\mathrm{NH}$ ), 7.28-7.52 (m, 11H, Ar-H); ${ }^{13}$ CNMR (DMSO-d 6 ) $\delta$ (ppm): 115, 120, 122, 125, 125, 127, 128, 131, 133, 134, 153; MS: $m / z=344[\mathrm{M}]^{+}$, 346 [M+2]. Anal. calcd. For $\mathrm{C}_{20} \mathrm{H}_{13} \mathrm{ClN}_{4}$ (344): C, 69.67; H, 3.80; N, 16.25. Found: C, 69.52; H, 3.74; N, 16.16.

(2) 2-(5-Bromo-3-phenyl-1H-indol-2-yl)-3H-imidazolo[4,5b]pyridine (3b). m.p. $267-268^{\circ} \mathrm{C}$; IR $(\mathrm{KBr}) \nu_{\max }\left(\mathrm{cm}^{-1}\right): 3435$, 3412; ${ }^{1} \mathrm{H}$ NMR (DMSO-d $6+\mathrm{CDCl}_{3}$ ) $\delta$ (ppm): 11.52 (s, $1 \mathrm{H}$, Indole $\mathrm{NH}$ ), 10.95 (s, 1H, Imidazolopyridine $\mathrm{NH}$ ), 7.21-7.69 (m, 11H, Ar-H); MS: $m / z=390[\mathrm{M}]^{+}, 392[\mathrm{M}+2]$. Anal. calcd. For $\mathrm{C}_{20} \mathrm{H}_{13} \mathrm{BrN}_{4}$ (390): C, 61.71; H, 3.37; N, 14.39. Found: C, $61.59 ; \mathrm{H}, 3.29 ; \mathrm{N}, 14.31$.

(3) 2-(5-Methyl-3-phenyl-1H-indol-2-yl)-3H-imidazolo[4,5b]pyridine (3c). m.p. $245-246^{\circ} \mathrm{C}$; IR (KBr) $\nu_{\max }\left(\mathrm{cm}^{-1}\right)$ : 3470 , 3418; ${ }^{1} \mathrm{H}$ NMR (DMSO-d $6+\mathrm{CDCl}_{3}$ ) $\delta$ (ppm): $11.66(\mathrm{~s}, 1 \mathrm{H}$, Indole $\mathrm{NH}$ ), 11.10 (s, 1H, Imidazolopyridine $\mathrm{NH}$ ), 7.10-7.48 (m, 11H, Ar-H), 2.41 (s, 3H, $\mathrm{CH}_{3}$ ); MS: $m / z=324[\mathrm{M}]^{+}$. Anal. calcd. for $\mathrm{C}_{21} \mathrm{H}_{16} \mathrm{~N}_{4}$ (324): C, 77.76; H, 4.97; N, 17.27. Found: C, 77.65; H, 4.91; N, 17.35.

(4) 2-(5-Methoxy-3-phenyl-1H-indol-2-yl)-3H-imidazolo[4,5b]pyridine (3d). m.p. $225-226^{\circ} \mathrm{C}$; IR (KBr) $\nu_{\max }\left(\mathrm{cm}^{-1}\right): 3341$, 2845; ${ }^{1} \mathrm{H}$ NMR (DMSO-d $6+\mathrm{CDCl}_{3}$ ) $\delta$ (ppm): 12.77 (s, $1 \mathrm{H}$, Indole $\mathrm{NH}$ ), 11.67 (s, $1 \mathrm{H}$, Imidazolopyridine $\mathrm{NH}$ ), 6.85-7.51 (m, 11H, Ar-H), 3.89 (s, 3H, $\mathrm{CH}_{3}$ ); MS: $m / z=340[\mathrm{M}]^{+}$. Anal. calcd. For $\mathrm{C}_{21} \mathrm{H}_{16} \mathrm{~N}_{4} \mathrm{O}(340)$ : C, 74.10; H, 4.74; N, 16.46. Found: C, 74.25; H, 4.68; N, 16.58.

(5) 2-(5-Chloro-3-methyl-1H-indol-2-yl)-3H-imidazolo[4,5b]pyridine (3e). m.p. $236-237^{\circ} \mathrm{C}$; IR $(\mathrm{KBr}) v_{\max }\left(\mathrm{cm}^{-1}\right): 3422$, 2849; ${ }^{1} \mathrm{H}$ NMR (DMSO-d $\left.6+\mathrm{CDCl}_{3}\right) \delta$ (ppm): $11.54(\mathrm{~s}, 1 \mathrm{H}$, Indole $\mathrm{NH}), 10.85$ ( $\mathrm{s}, 1 \mathrm{H}$, Imidazolopyridine $\mathrm{NH}), 7.21-7.69$ (m, 6H, Ar-H), 2.50 (s, 3H, $\mathrm{CH}_{3}$ ); MS: $m / z=282[\mathrm{M}]^{+.}, 284$ [M+2]. Anal. calcd. For $\mathrm{C}_{15} \mathrm{H}_{11} \mathrm{ClN}_{4}$ (282): C, 63.72; H, 3.92; N, 19.82. Found: C, 63.67; H, 3.85; N, 19.71 .

(6) 2-(5-Bromo-3-methyl-1H-indol-2-yl)-3H-imidazolo[4,5b]pyridine (3f). m.p. $256-257^{\circ} \mathrm{C}$; IR $(\mathrm{KBr}) v_{\max }\left(\mathrm{cm}^{-1}\right): 3439$, 2849; ${ }^{1} \mathrm{H}$ NMR (DMSO-d 6 $+\mathrm{CDCl}_{3}$ ) $\delta$ (ppm): 11.53 (s, $1 \mathrm{H}$, 
Indole $\mathrm{NH}$ ), 11.00 (s, 1H, Imidazolopyridine $\mathrm{NH}$ ), 7.44-8.04 (m, 11H, Ar-H), 2.44 (s, 3H, $\mathrm{CH}_{3}$ ); MS: $m / z=328[\mathrm{M}]^{+}, 330$ $[\mathrm{M}+2]$. Anal. calcd. For $\mathrm{C}_{15} \mathrm{H}_{11} \mathrm{BrN}_{4}$ (328): C, 55.06; H, 3.39; N, 17.12. Found: C, 55.12; H, 3.31; N, 17.07.

(7) 2-(3,5-Dimethyl-1H-indol-2-yl)-3H-imidazolo[4,5-b]pyridine (3g). m.p. $240-241^{\circ} \mathrm{C}$; IR (KBr) $\nu_{\max }\left(\mathrm{cm}^{-1}\right)$ : 3422, 2852; ${ }^{1} \mathrm{H}$ NMR (DMSO-d $\mathrm{d}_{6}+\mathrm{CDCl}_{3}$ ) $\delta$ (ppm): 11.17 (s, 1H, Indole $\mathrm{NH}$ ), 9.83 (s, 1H, Imidazolopyridine NH), 7.22-7.78 (m, Ar-H, $6 \mathrm{H}$ ), 2.07 (d, 6H, $\mathrm{CH}_{3}$ ); ${ }^{13} \mathrm{CNMR}\left(\mathrm{DMSO}_{6} \mathrm{~d}_{6}\right) \delta$ (ppm): 21, 10, 112 , 118, 120, 124, 127, 128, 128, 135, 164; MS: $m / z=262[\mathrm{M}]^{+}$. Anal. calcd. For $\mathrm{C}_{16} \mathrm{H}_{14} \mathrm{~N}_{4}$ (262): C, 73.26; H, 5.38; N, 21.36. Found: C, 73.19; H, 5.29; N, 21.28.

(8) 2-(5-Methoxy-3-methyl-1H-indol-2-yl)-3H-imidazolo[4,5b]pyridine (3h). m.p. $275-276^{\circ} \mathrm{C}$; IR (KBr) $\nu_{\max }\left(\mathrm{cm}^{-1}\right): 3422$, 2852; ${ }^{1} \mathrm{H}$ NMR (DMSO-d $\left.6+\mathrm{CDCl}_{3}\right) \delta(\mathrm{ppm}): 12.77(\mathrm{~s}, 1 \mathrm{H}$, Indole $\mathrm{NH}$ ), 11.20 (s, $1 \mathrm{H}$, Imidazolopyridine $\mathrm{NH}$ ), 7.05-7.38 (m, Ar-H, 6H), 2.50 (S, 3H, $\mathrm{CH}_{3}$ ), 3.34 (S, 3H, $\mathrm{OCH}_{3}$ ); MS: $m / z=278[\mathrm{M}]^{+}$. Anal. calcd. For $\mathrm{C}_{16} \mathrm{H}_{14} \mathrm{~N}_{4} \mathrm{O}$ (278): C, 69.05; H, 5.07; N, 20.13. Found: C, 68.45; H, 5.01; N, 20.01.

(9) 2-(1H-Indol-2-yl)-3H-imidazolo[4,5-b]pyridine (3i). m.p. 238-239 ${ }^{\circ} \mathrm{C}$; IR (KBr) $v_{\max }\left(\mathrm{cm}^{-1}\right): 3207,2952 ;{ }^{1} \mathrm{H}$ NMR $\left(\mathrm{DMSO}-\mathrm{d}_{6}+\mathrm{CDCl}_{3}\right) \delta$ (ppm): 12.304 (s, 1H, Indole $\mathrm{NH}$ ), 10.98 (s, 1H, Imidazolopyridine $\mathrm{NH}$ ), 6.54-7.53 (m, Ar-H, $6 \mathrm{H})$; MS: $m / z=234[\mathrm{M}]^{+.}$. Anal. calcd. For $\mathrm{C}_{14} \mathrm{H}_{10} \mathrm{~N}_{4}$ (234): C, 71.78; H, 4.30; N, 23.92. Found: C, 71.65; H, 4.25; N, 23.85.

\subsection{Biological Activities}

\subsubsection{Antioxidant Activities}

(1) Free Radical Scavenging Activity. Free radical scavenging activity was done by DPPH method [45]. Different concentrations $(10,50$, and $100 \mu \mathrm{g})$ of samples and butylated hydroxy anisole (BHA) were taken in different test tubes. The volume was adjusted to $100 \mu \mathrm{L}$ by adding $\mathrm{MeOH}$. Five milliliters of $0.1 \mathrm{mM}$ methanolic solution of DPPH was added to these tubes and shaken vigorously. The tubes were allowed to stand at $27^{\circ} \mathrm{C}$ for $20 \mathrm{~min}$. The control was prepared as above without any extract. The absorbance of samples was measured at $517 \mathrm{~nm}$. Radical scavenging activity was calculated using the following formula:

\% Radical scavenging activity

$$
=\left[\frac{\text { Control OD }- \text { Sample OD }}{\text { Control OD }}\right] \times 100 \text {. }
$$

(2) Total Antioxidant Capacity. Various concentrations of extracts $(10,50$, and $100 \mu \mathrm{g})$ were taken in a series of test tubes. To this, $1.9 \mathrm{~mL}$ of reagent solution $(0.6 \mathrm{M}$ sulfuric acid, $28 \mathrm{mM}$ sodium phosphate, and $4 \mathrm{mM}$ ammonium molybdate) was added. The tubes were incubated at $95^{\circ} \mathrm{C}$ for $90 \mathrm{~min}$ and allowed to cool. The absorbance of each aqueous solution was measured at $695 \mathrm{~nm}$ against a blank. Antioxidant capacities are expressed as equivalents of ascorbic acid. Ascorbic acid equivalents are calculated using standard graph of ascorbic acid. The values are expressed as ascorbic acid equivalents in $\mu \mathrm{g}$ per mg of extract.
(3) Ferric Reducing Antioxidant Power. Various concentrations of extracts $(10,50$, and $100 \mu \mathrm{g})$ were mixed with $2.5 \mathrm{~mL}$ of $200 \mathrm{mmol} / \mathrm{L}$ sodium phosphate buffer ( $\mathrm{pH} 6.6$ ) and $2.5 \mathrm{~mL}$ of $1 \%$ potassium ferricyanide. The mixture was incubated at $50^{\circ} \mathrm{C}$ for $20 \mathrm{~min}$. Next, $2.5 \mathrm{~mL}$ of $10 \%$ trichloroacetic acid $(\mathrm{w} / \mathrm{v})$ was added. From this solution, $5 \mathrm{~mL}$ was mixed with $5 \mathrm{~mL}$ of distilled water and $1 \mathrm{~mL}$ of $0.1 \%$ ferric chloride and absorbance was measured spectrophotometrically at $700 \mathrm{~nm}$. BHA was used as standard.

2.2.2. Antimicrobial Activity. A series of novel imidazolopyridinyl indole analogues are tested for in vitro antimicrobial activity against gram-negative bacteria Escherichia coli ATCC 25922 and Klebsiella Pneumoniae ATCC 33499 and grampositive bacteria Staphylococcus aureus ATCC 6538 and antifungal activity against Candida tropicalis ATCC 8302 and Candida albicans ATCC 60193 by applying the agar plate diffusion technique [46]. Dilution process was adopted at 25, 50 , and $100 \mu \mathrm{g} / \mathrm{mL}$ concentrations. The activity is compared with reference drugs Gentamycin for antibacterial and Fluconazole for antifungal activity. The zone of inhibition after $24 \mathrm{hr}$ of incubation at $37^{\circ} \mathrm{C}$, in case of antibacterial activity and $48 \mathrm{hr}$ in case of antifungal activity, was compared with that of standards.

\section{Results and Discussion}

3.1. Chemistry. The compounds were designed with the aim of exploring their antioxidant and antimicrobial activities. The target compounds were synthesized as outlined in Scheme 1. 3,5-Disubstituted indol-2-carboxylic acids (1ai) were reacted with 2,3-diaminopyridine (2) in ethanol affords imidazolopyridinyl indoles. Completion of the reaction was monitored by TLC. All the novel compounds were characterized by elemental analysis and IR, ${ }^{1} \mathrm{H} N M R$, ${ }^{13} \mathrm{C} \mathrm{NMR}$, and mass spectroscopic data. The IR spectrum of 2-(5-chloro-3-phenyl-1H-indol-2-yl)-3H-imidazo[4, 5-b]pyridine $3 \mathbf{a}$ showed strong absorption at $3449 \mathrm{~cm}^{-1}$ corresponding to indole $\mathrm{NH}$ and absorption at $3416 \mathrm{~cm}^{-1}$ corresponding to imidazolopyridine $\mathrm{NH}$. The ${ }^{1} \mathrm{HNMR}$ spectrum of 3a has exhibited a singlet at $\delta 12.02$ due to indole $\mathrm{NH}$; singlet at $\delta 11.50$ corresponds to imidazolopyridine $\mathrm{NH}$ which are $\mathrm{D}_{2} \mathrm{O}$ exchangeable. A multiplet between $\delta$ $7.28-7.52$ is assigned to the eleven aromatic protons present in the molecule. The ${ }^{13} \mathrm{CNMR}$ spectrum of 3 a has shown peaks at $\delta 115,120,122,125,125,127,128,131,133,134$, and 153. The mass spectrum of compound $\mathbf{3 a}$ has shown isotopic peaks at $m / z 344[\mathrm{M}]^{+}, 346[\mathrm{M}+2]$. The above spectral data supports the formation of compound 3a. The various new indole derivatives synthesized during the present investigation are listed in Table 1.

3.2. Biological Activities. The target compounds 3a-i have been synthesized as illustrated in Scheme 1 and screened for antioxidant (free radical scavenging, total antioxidant capacity and ferric reducing antioxidant power) and antimicrobial activities. 
TABLE 1: Comparative data of conventional and microwave method for the imidazolopyridinyl indole analogues 3a-i.

\begin{tabular}{|c|c|c|c|c|c|c|c|}
\hline \multirow{2}{*}{ Product } & \multicolumn{2}{|c|}{ Substituent's } & \multicolumn{2}{|c|}{ Conventional method } & \multicolumn{3}{|c|}{ Microwave method } \\
\hline & $\mathrm{R}$ & $\mathrm{R}^{\prime}$ & Time (Min) & Yield $(\%)^{\mathrm{a}}$ & Time (Min) & Power & Yield $(\%)^{\mathrm{a}}$ \\
\hline $3 \mathbf{a}$ & $\mathrm{Cl}$ & $\mathrm{Ph}$ & $300-360$ & 75 & 10 & 70 & 98 \\
\hline $3 \mathbf{b}$ & $\mathrm{Br}$ & $\mathrm{Ph}$ & $300-360$ & 70 & 10 & 70 & 97 \\
\hline $3 c$ & $\mathrm{Me}$ & $\mathrm{Ph}$ & $300-360$ & 60 & 10 & 70 & 95 \\
\hline $3 d$ & $\mathrm{OMe}$ & $\mathrm{Ph}$ & $300-360$ & 60 & 10 & 70 & 95 \\
\hline $3 e$ & $\mathrm{Cl}$ & $\mathrm{Me}$ & $300-360$ & 75 & 10 & 70 & 98 \\
\hline $3 f$ & $\mathrm{Br}$ & $\mathrm{Me}$ & $300-360$ & 75 & 10 & 70 & 98 \\
\hline $3 g$ & $\mathrm{Me}$ & $\mathrm{Me}$ & $300-360$ & 60 & 10 & 70 & 94 \\
\hline $3 \mathbf{h}$ & $\mathrm{OMe}$ & $\mathrm{Me}$ & $300-360$ & 60 & 10 & 70 & 94 \\
\hline $3 \mathbf{i}$ & $\mathrm{H}$ & $\mathrm{H}$ & $300-360$ & 60 & 10 & 70 & 80 \\
\hline
\end{tabular}

${ }^{\mathrm{a}}$ Isolated yields.<smiles>[R]c1ccc2[nH]c(C(=O)O)c([R])c2c1</smiles>

(1a-i) 2<smiles>[R]c1ccc2[nH]c(-c3nc4cccnc4[nH]3)c([R])c2c1</smiles>

(3a-i)

$$
\begin{array}{cccccccccc} 
& \mathbf{a} & \mathbf{b} & \mathbf{c} & \mathbf{d} & \mathbf{e} & \mathbf{f} & \mathbf{g} & \mathbf{h} & \mathbf{i} \\
\mathrm{R} & \mathrm{Cl} & \mathrm{Br} & \mathrm{CH}_{3} & \mathrm{OCH}_{3} & \mathrm{Cl} & \mathrm{Br} & \mathrm{CH}_{3} & \mathrm{OCH}_{3} & \mathrm{H} \\
\mathrm{R}^{\prime} & \mathrm{Ph} & \mathrm{Ph} & \mathrm{Ph} & \mathrm{Ph} & \mathrm{CH}_{3} & \mathrm{CH}_{3} & \mathrm{CH}_{3} & \mathrm{CH}_{3} & \mathrm{H}
\end{array}
$$

SCHEME 1: Schematic representation of the synthesized novel imidazolopyridinyl indoles $\mathbf{3 a - i}$.

\subsubsection{Antioxidant Activities}

(1) Free Radical Scavenging Activity. The target compounds were screened for free radical scavenging activity by DPPH method [45]. The samples were prepared at concentrations of 10,50 , and $100 \mu \mathrm{g} / 100 \mu \mathrm{L}$ and butylated hydroxy anisole (BHA) is taken as standard. DPPH is a stable free radical in a methanolic solution. Because of the unpaired electron of $\mathrm{DPPH}$, it gives a strong absorption maximum at $517 \mathrm{~nm}$ by visible spectroscopy (purple color). In addition, the unpaired electron of the radical becomes paired in the presence of a hydrogen donor (a free radical scavenging antioxidant), decreasing the absorption. Therefore, DPPH loses color in

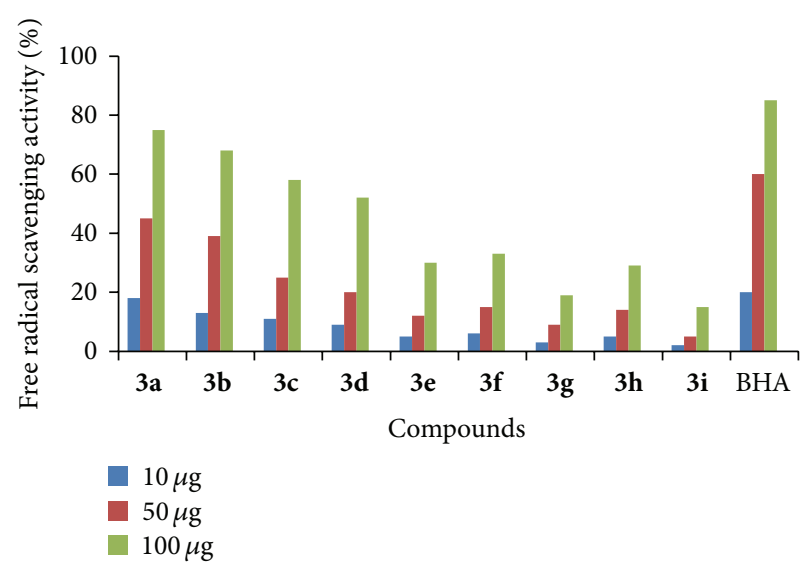

FIGURE 1: Free radical scavenging activity of $\mathbf{3 a - i}$.

proportion to the number of electrons captured [47]. This reaction has been widely used as a simple, rapid, and convenient method independent of sample polarity for screening many samples for radical scavenging activity $[48,49]$. These advantages have made the DPPH method interesting for testing our analogs. Among the tested compounds, 3a-d has shown very potent scavenging activity. The increased scavenging activity is due to the presence of halogen, methyl, and methoxy substitution at the five positions and a phenyl ring at the third position of indole ring. The hydrogen of indole $\mathrm{NH}$ /imidazolopyridine $\mathrm{NH}$ could be donated to the $\mathrm{DPPH}$ to form DPPH free radical; by the presence of phenyl ring at third position of indole, the DPPH free radical will be stabilized by the resonance. Compounds $\mathbf{3 e - h}$ have shown equipotent activities. The decreased activity is due to the presence of " $\mathrm{H}$ " at five positions of indole ring. The bar graph representation of percentage of free radical scavenging activity is shown in Figure 1.

(2) Total Antioxidant Capacity. Total antioxidant activity was performed on all the newly synthesized compounds [50]. Antioxidant capacities are expressed as equivalents of ascorbic acid. Among the tested compounds, 3a-d have shown excellent activity. The results of total antioxidant activity are shown in Figure 2. 
TABLE 2: Antibacterial activity of synthesized compounds $\mathbf{3 a - i}$ (zone of inhibition in $\mathrm{mm}$ ).

\begin{tabular}{|c|c|c|c|c|c|c|c|c|c|}
\hline \multirow{3}{*}{ Compound } & \multicolumn{9}{|c|}{ Antibacterial activity } \\
\hline & \multicolumn{3}{|c|}{ S. aureus } & \multicolumn{3}{|c|}{ E. coli } & \multicolumn{3}{|c|}{ K. Pneumoniae } \\
\hline & 25 & 50 & 100 & 25 & 50 & 100 & 25 & 50 & 100 \\
\hline $3 \mathbf{a}$ & 11 & 13 & 15 & 10 & 11 & 13 & 11 & 12 & 14 \\
\hline $3 \mathbf{b}$ & 12 & 14 & 14 & 11 & 12 & 12 & 10 & 12 & 15 \\
\hline $3 c$ & 10 & 13 & 14 & 09 & 11 & 12 & 10 & 12 & 13 \\
\hline $3 d$ & 12 & 15 & 13 & 10 & 10 & 12 & 09 & 12 & 13 \\
\hline $3 e$ & 08 & 09 & 10 & 04 & 06 & 06 & 05 & 06 & 07 \\
\hline $3 f$ & 05 & 07 & 09 & 05 & 07 & 08 & 04 & 06 & 06 \\
\hline $3 g$ & 07 & 06 & 08 & 06 & 07 & 08 & 06 & 08 & 09 \\
\hline $3 h$ & 08 & 08 & 09 & 06 & 06 & 09 & 07 & 06 & 08 \\
\hline $3 \mathbf{i}$ & 05 & 05 & 05 & 03 & 04 & 03 & 05 & 04 & 05 \\
\hline Std. 1 & 12 & 14 & 15 & 10 & 12 & 13 & 11 & 13 & 15 \\
\hline
\end{tabular}

Std. 1: Gentamycin.

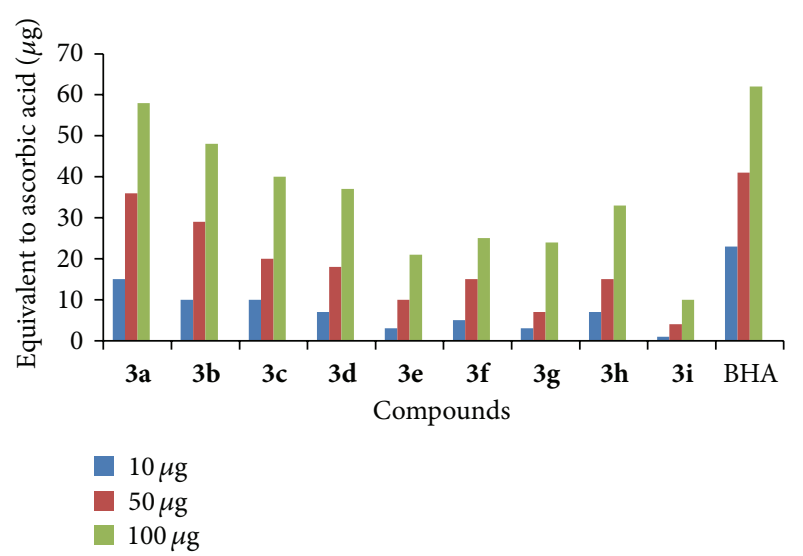

FIgURE 2: Total antioxidant activity of $\mathbf{3 a - i}$.

(3) Ferric Reducing Antioxidant Power Activity. All the novel compounds were screened for ferric reducing antioxidant activity [51]. Butylated hydroxy anisole (BHA) was used as standard. All the tested compounds have shown a positive tendency towards the ferric reducing activity. The presence of reducer (i.e., antioxidant) causes the reduction of the $\mathrm{Fe}^{+3}$ /ferricyanide complex to the ferrous form after the addition of trichloroacetic acid and ferric chloride. The reducing power of test compounds increases with increase in concentration. Compounds $\mathbf{3} \mathbf{c}-\mathbf{d}$ and $\mathbf{3 g}-\mathbf{h}$ have shown excellent ferric reducing activity and $\mathbf{3 a - b}$ and $\mathbf{3 e - f}$ have shown moderate to high activity. The presence of methyl and methoxy groups at five positions of indole ring has enhanced the ferric reducing power activity of the compounds. The results are presented in Figure 3.

3.2.2. Antimicrobial Activity. Results of antimicrobial activity are summarized in Tables 2 and 3. Applying the agar plate diffusion technique [46], a series of novel imidazolopyridinyl indole analogues were screened for in vitro antibacterial activity against gram-negative bacteria Escherichia coli (E. coli) and Klebsiella Pneumoniae (K. Pneumoniae) and
TABLE 3: Antifungal activity of synthesized compounds $\mathbf{3 a - i}$ (zone of inhibition in $\mathrm{mm}$ ).

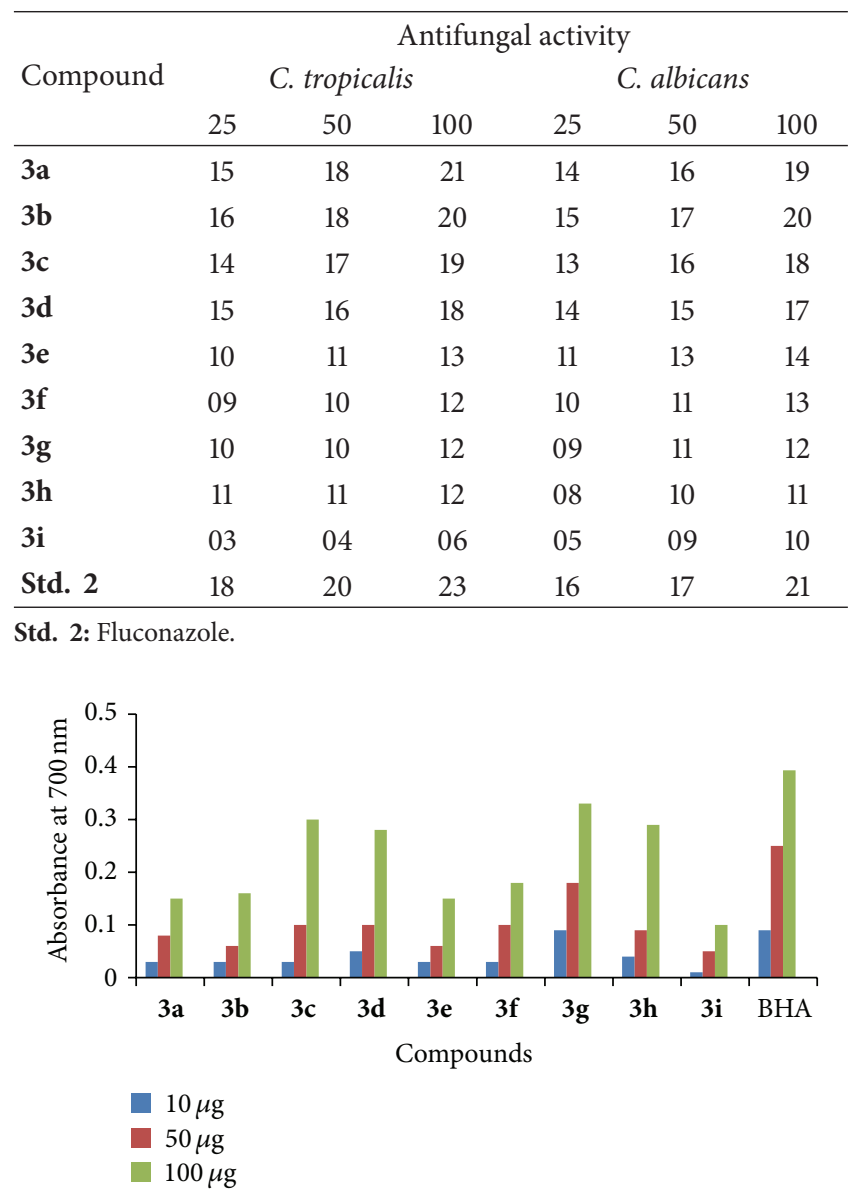

FIgURE 3: Ferric reducing antioxidant power activity of $\mathbf{3 a - i}$.

gram-positive bacteria Staphylococcus aureus (S. aureus) at $25 \mu \mathrm{g} / \mathrm{mL}, 50 \mu \mathrm{g} / \mathrm{mL}$, and $100 \mu \mathrm{g} / \mathrm{mL}$ concentrations, respectively. Gentamycin was used as standard. The zones of inhibitions were measured in $\mathrm{mm}$ for each concentration. Most 
of the screened compounds were found to have significant antibacterial activity. Compounds $\mathbf{3 a - d}$ have shown very good activity against all three bacterial strains. Antifungal screening of the compounds was carried out in vitro against two fungi Candida tropicalis and Candida albicans at $25 \mu \mathrm{g} / \mathrm{mL}, 50 \mu \mathrm{g} / \mathrm{mL}$, and $100 \mu \mathrm{g} / \mathrm{mL}$ concentrations using Fluconazole as standard. Among the tested imidazolopyridinyl indole systems, the majority of the compounds exhibited moderate to significant antifungal activity.

\section{Conclusion}

In conclusion, we have synthesized title compound $\mathbf{3 a}-\mathbf{i}$ by a safer method. The title compound $\mathbf{3 a - i}$ was subjected to screening for its antioxidant and antimicrobial activities. Compounds 3a-d have shown profound scavenging and antioxidant activities. Compounds $\mathbf{3 c}-\mathbf{d}$ and $\mathbf{3 g}$-h have shown excellent ferric reducing activity and compounds $\mathbf{3 a - d}$ have shown very promising antimicrobial activity. Very promising scavenging, antioxidant, and antimicrobial activities are observed with compounds containing halogens, methyl, and methoxy groups at five positions and a phenyl ring at the third position of indole ring. Excellent ferric reducing activity is observed with compounds containing $\mathrm{CH}_{3}$ and $\mathrm{OCH}_{3}$ at five positions of indole. Development of new methodologies for the synthesis of indole derivatives will be very important to the chemists, which will yield subsets of heterocycles having potentiality to serve as templates for new biologically active molecules. Hence, investigation by rapid means to make novel imidazolopyridinyl indoles would be highly beneficial.

\section{Conflict of Interests}

The authors declare that there is no conflict of interests regarding the publication of this paper.

\section{Acknowledgments}

The authors are grateful to the Department of Chemistry, Gulbarga University, Gulbarga, for providing facilities to carry out research work. The authors thank the Director of IISc, Bangalore, and IIT, Madras, for spectroscopic analysis. In addition the authors thank BioGenics, Hubli, for their assistance in carrying out antioxidant activity. The authors also thank the Department of Microbiology in carrying out antimicrobial activity.

\section{References}

[1] M. A. Martinez-Urbina, A. Zentella, M. A. Vilchis-Reyes et al., "6-Substituted 2-(N-trifluoroacetylamino) imidazopyridines induce cell cycle arrest and apoptosis in SK-LU-1 human cancer cell line," European Journal of Medicinal Chemistry, vol. 45, no. 3, pp. 1211-1219, 2010.

[2] Y. Gilgun-Sherki, E. Melamed, and D. Offen, "Oxidative stress induced-neurodegenerative diseases: the need for antioxidants that penetrate the blood brain barrier," Neuropharmacology, vol. 40, no. 8, pp. 959-975, 2001.
[3] L. Horakova and S. Stolc, "Antioxidant and pharmacodynamic effects of pyridoindole stobadine," General Pharmacology, vol. 30, no. 5, pp. 627-638, 1998.

[4] M. Valko, C. J. Rhodes, J. Moncol, M. Izakovic, and M. Mazur, "Free radicals, metals and antioxidants in oxidative stressinduced cancer," Chemico-Biological Interactions, vol. 160, no. 1, pp. 1-40, 2006.

[5] D. Venkat Ratnam, D. D. Ankola, V. Bhardwaj, D. K. Sahana, and M. N. V. Ravi Kumar, "Role of antioxidants in prophylaxis and therapy: a pharmaceutical perspective," Journal of Controlled Release, vol. 113, no. 3, pp. 189-207, 2006.

[6] M.-H. Shih and F.-Y. Ke, "Syntheses and evaluation of antioxidant activity of sydnonyl substituted thiazolidinone and thiazoline derivatives," Bioorganic and Medicinal Chemistry, vol. 12, no. 17, pp. 4633-4643, 2004.

[7] B. P. Bandgar, L. K. Adsul, H. V. Chavan et al., "Synthesis, biological evaluation and docking studies of 3-(substituted)aryl-5-(9-methyl-3-carbazole)-1H-2-pyrazolines as potent antiinflammatory and antioxidant agents," Bioorganic and Medicinal Chemistry Letters, vol. 22, no. 18, pp. 5839-5844, 2012.

[8] J. Liu, L. Cao, and T. Finkel, "Oxidants, metabolism, and stem cell biology," Free Radical Biology and Medicine, vol. 51, no. 12, pp. 2158-2162, 2011.

[9] Y. Hangun-Balkir and M. L. McKenney, "Determination of antioxidant activities of berries and resveratrol," Green Chemistry Letters and Reviews, vol. 5, no. 2, pp. 147-153, 2012.

[10] M. Kataoka, K. Tonooka, T. Ando, K. Imai, and T. Aimoto, "Hydroxyl radical scavenging activity of nonsteroidal antiinflammatory drugs," Free Radical Research, vol. 27, no. 4, pp. 419-427, 1997.

[11] G. L. Squadrito and W. A. Pryor, "Oxidative chemistry of nitric oxide: the roles of superoxide, peroxynitrite, and carbon dioxide," Free Radical Biology and Medicine, vol. 25, no. 4-5, pp. 392403, 1998.

[12] E. Esposito, D. Rotilio, V. Di Matteo, C. Di Giulio, M. Cacchio, and S. Algeri, "A review of specific dietary antioxidants and the effects on biochemical mechanisms related to neurodegenerative processes," Neurobiology of Aging, vol. 23, no. 5, pp. 719-735, 2002.

[13] G. Waris and H. Ahsan, "Reactive oxygen species: role in the development of cancer and various chronic conditions," Journal of Carcinogenesis, vol. 5, article 14, 2006.

[14] J. S. Francis, M. C. Doherty, U. Lopatin et al., "Severe community-onset pneumonia in healthy adults caused by methicillinresistant Staphylococcus aureus carrying the Panton-Valentine leukocidin genes," Clinical Infectious Diseases, vol. 40, no. 1, pp. 100-107, 2005.

[15] D. Kruszewska, H.-G. Sahl, G. Bierbaum, U. Pag, S. O. Hynes, and A. Ljungh, "Mersacidin eradicates methicillin-resistant Staphylococcus aureus (MRSA) in a mouse rhinitis model," Journal of Antimicrobial Chemotherapy, vol. 54, no. 3, pp. 648-653, 2004.

[16] R. K. Pettit, G. D. Cage, G. R. Pettit, and J. A. Liebman, "Antimicrobial and cancer cell growth inhibitory activities of $3 \beta$ acetoxy-17 $\beta$-(L-prolyl)amino- $5 \alpha$-androstane in vitro," International Journal of Antimicrobial Agents, vol. 15, no. 4, pp. 299-304, 2000.

[17] S. A. Khan, A. M. Asiri, and M. Yusuf, "Synthesis and biological evaluation of some thiazolidinone derivatives of steroid as antibacterial agents," European Journal of Medicinal Chemistry, vol. 44, no. 6, pp. 2597-2600, 2009. 
[18] A. C. Humphries, E. Gancia, M. T. Gilligan et al., "8-Fluoroimidazo[1,2-a]pyridine: synthesis, physicochemical properties and evaluation as a bioisosteric replacement for imidazo[1,2a]pyrimidine in an allosteric modulator ligand of the GABAA receptor," Bioorganic and Medicinal Chemistry Letters, vol. 16, no. 6, pp. 1518-1522, 2006.

[19] A. Kocabalkanli and R. F. Schinazi, "Synthesis of oxathiolane imidazole nucleosides," Il Farmaco, vol. 57, no. 12, pp. 993-997, 2002.

[20] R. Kumar and J. W. Lown, "Design, synthesis and in vitro cytotoxic studies of novel bis-pyrrolo[2,1][1,4] benzodiazepinepyrrole and imidazole polyamide conjugates," European Journal of Medicinal Chemistry, vol. 40, no. 7, pp. 641-654, 2005.

[21] A. Foroumadi, M. Mirzaei, and A. Shafiee, "Antituberculosis agents II. evaluation of in vitro antituberculosis activity and cytotoxicity of some 2-(1-methyl-5-nitro-2-imidazolyl)-1,3,4thiadiazole derivatives," Il Farmaco, vol. 56, no. 8, pp. 621-623, 2001.

[22] D. E. Frantz, L. Morency, A. Soheili, J. A. Murry, E. J. J. Grabowski, and R. D. Tillyer, "Synthesis of substituted imidazoles via organocatalysis," Organic Letters, vol. 6, no. 5, pp. 843-846, 2004.

[23] H. Banie, A. Sinha, R. J. Thomas, J. C. Sircar, and M. L. Richards, "2-Phenylimidazopyridines, a new series of golgi compounds with potent antiviral activity," Journal of Medicinal Chemistry, vol. 50, no. 24, pp. 5984-5993, 2007.

[24] R. B. Lacerda, C. K. F. De Lima, L. L. Da Silva et al., "Discovery of novel analgesic and anti-inflammatory 3-arylamineimidazo[1,2-a]pyridine symbiotic prototypes," Bioorganic and Medicinal Chemistry, vol. 17, no. 1, pp. 74-84, 2009.

[25] K. S. Gudmundsson, S. D. Boggs, J. G. Catalano et al., "Imidazopyridine-5,6,7,8-tetrahydro-8-quinolinamine derivatives with potent activity against HIV-1," Bioorganic and Medicinal Chemistry Letters, vol. 19, no. 22, pp. 6399-6403, 2009.

[26] D. B. Sanders, "3,4-Diaminopyridine (DAP) in the treatment of Lambert-Eaton myasthenic syndrome (LEMS)," Annals of the New York Academy of Sciences, vol. 841, pp. 811-816, 1998.

[27] S. I. V. Judge and C. T. Bever Jr., "Potassium channel blockers in multiple sclerosis: neuronal $\mathrm{Kv}$ channels and effects of symptomatic treatment," Pharmacology and Therapeutics, vol. 111, no. 1, pp. 224-259, 2006.

[28] G. D. P. Doherty, "Rodenticidal imidazo-pyridines," US Patent, 3, 941, 882; Chemical Abstracts 79, 14235a, 1976.

[29] J. A. Montgomery and K. Hewson, "3-Deaza-6-methylthiopurine ribonucleoside," Journal of Medicinal Chemistry, vol. 9, no. 1, pp. 105-107, 1966.

[30] I. M. Khan, A. Ahmad, and S. Kumar, "Synthesis, spectroscopic characterization and structural investigations of a new charge transfer complex of 2,6-diaminopyridine with 3,5- dinitrobenzoic acid: DNA binding and antimicrobial studies," Journal of Molecular Structure, vol. 1035, no. 13, pp. 38-45, 2013.

[31] R. J. Sundberg, The Chemistry of Indoles, Academic Press, New York, NY, USA, 1996.

[32] M. S. Estevao, L. C. Carvalho, L. M. Ferreira, E. Fernandes, and M. M. B. Marques, "Analysis of the antioxidant activity of an indole library: cyclic voltammetry versus ROS scavenging activity," Tetrahedron Letters, vol. 52, no. 1, pp. 101-106, 2011.

[33] M. Pojarova, D. Kaufmann, R. Gastpar et al., "[(2-Phenylindol3-yl)methylene] propanedinitriles inhibit the growth of breast cancer cells by cell cycle arrest in G2/M phase and apoptosis," Bioorganic and Medicinal Chemistry, vol. 15, no. 23, pp. 73687379, 2007.
[34] Y.-S. Wu, M. S. Coumar, J.-Y. Chang et al., "Synthesis and evaluation of 3-aroylindoles as anticancer agents: metabolite approach," Journal of Medicinal Chemistry, vol. 52, no. 15, pp. 4941-4945, 2009.

[35] J. S. Biradar and B. S. Sasidhar, "Solvent-free, microwave assisted Knoevenagel condensation of novel 2,5-disubstituted indole analogues and their biological evaluation," European Journal of Medicinal Chemistry, vol. 46, no. 12, pp. 6112-6118, 2011.

[36] J. S. Biradar, B. S. Sasidhar, and R. Parveen, "Synthesis, antioxidant and DNA cleavage activities of novel indole derivatives," European Journal of Medicinal Chemistry, vol. 45, no. 9, pp. 4074-4078, 2010.

[37] J. S. Biradar, R. Parveen, B. S. Sasidhar, and S. M. Praveen, "Synthesis of new indolyl benzodiazepines and their DNA cleavage and antimicrobial activities," Indian Journal of Heterocyclic Chemistry, vol. 20, pp. 181-182, 2010.

[38] E. Buyukbingol, S. Suzen, and G. Klopman, "Studies on the synthesis and structure-activity relationships of 5-( $3^{\prime}$-indolal)2-thiohydantoin derivatives as aldose reductase enzyme inhibitors," Il Farmaco, vol. 49, no. 6, pp. 443-447, 1994.

[39] P. Lavanya, M. Suresh, Y. Kotaiah, N. Harikrishna, and C. Venkata Rao, "Synthesis, antibacterial, antifungal and antioxidant activity studies on 6-bromo-2-substitutedphenyl-1Himidazo [4, 5-b] pyridine," Asian Journal of Pharmaceutical and Clinical Research, vol. 4, no. 4, pp. 69-73, 2011.

[40] K. Niknam and A. Fatehi-Raviz, "Synthesis of 2-substituted benzimidazoles and bis-benzimidazoles by microwave in the presence of alumina-methanesulfonic acid," Journal of the Iranian Chemical Society, vol. 4, no. 4, pp. 438-443, 2007.

[41] V. M. Reddy and K. R. Reddy, "Synthesis and antimicrobial activity of some novel 4-(1H-benz[d]imidazol-2yl)-1,3-thiazol2-amines," Chemical and Pharmaceutical Bulletin, vol. 58, no. 7, pp. 953-956, 2010.

[42] L. C. W. Chang, J. K. Von Frijtag Drabbe Künzel, T. MulderKrieger et al., "2,6,8-Trisubstituted 1-deazapurines as adenosine receptor antagonists," Journal of Medicinal Chemistry, vol. 50, no. 4, pp. 828-834, 2007.

[43] R. V. Shingalapur, K. M. Hosamani, and R. S. Keri, "Synthesis and evaluation of in vitro anti-microbial and anti-tubercular activity of 2-styryl benzimidazoles," European Journal of Medicinal Chemistry, vol. 44, no. 10, pp. 4244-4248, 2009.

[44] J. S. Biradar, Studies in the Indole field [Ph.D. thesis], Gulbarga University, Gulbarga, India, 1982.

[45] R. P. Singh, K. N. C. Murthy, and G. K. Jayaprakasha, "Studies on the antioxidant activity of pomegranate (Punica granatum) peel and seed extracts using in vitro models," Journal of Agricultural and Food Chemistry, vol. 50, no. 1, pp. 81-86, 2002.

[46] C. Praveen, A. Ayyanar, and P. T. Perumal, "Practical synthesis, anticonvulsant, and antimicrobial activity of $\mathrm{N}$-allyl and $\mathrm{N}$ propargyl di(indolyl)indolin-2-ones," Bioorganic and Medicinal Chemistry Letters, vol. 21, no. 13, pp. 4072-4077, 2011.

[47] M. S. Blois, "Antioxidant determinations by the use of a stable free radical," Nature, vol. 181, no. 4617, pp. 1199-1200, 1958.

[48] I. I. Koleva, T. A. Van Beek, J. P. H. Linssen, A. De Groot, and L. N. Evstatieva, "Screening of plant extracts for antioxidant activity: a comparative study on three testing methods," Phytochemical Analysis, vol. 13, no. 1, pp. 8-17, 2002.

[49] P. Molyneux, "The use of the stable free radical diphenylpicrylhydrazyl (DPPH) for estimating antioxidant activity," Songklanakarin Journal of Science and Technology, vol. 26, no. 2, pp. 211-219, 2004. 
[50] M. Curcio, F. Puoci, F. Iemma et al., "Covalent insertion of antioxidant molecules on chitosan by a free radical grafting procedure," Journal of Agricultural and Food Chemistry, vol. 57, no. 13, pp. 5933-5938, 2009.

[51] J. C. M. Barreira, I. C. F. R. Ferreira, M. B. P. P. Oliveira, and J. A. Pereira, "Antioxidant activity and bioactive compounds of ten Portuguese regional and commercial almond cultivars," Food and Chemical Toxicology, vol. 46, no. 6, pp. 2230-2235, 2008. 

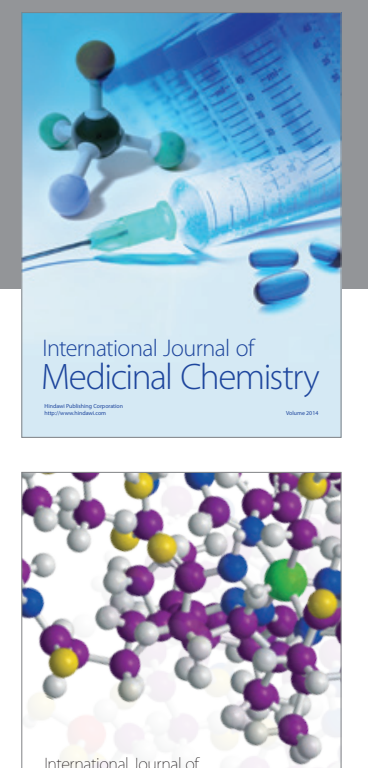

\section{Carbohydrate} Chemistry

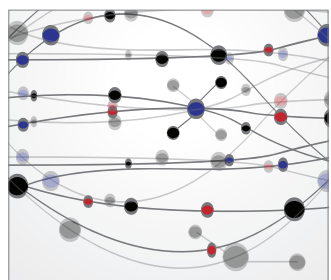

The Scientific World Journal
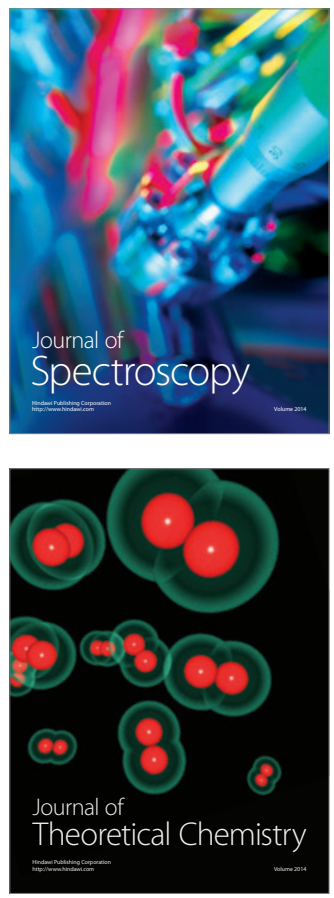
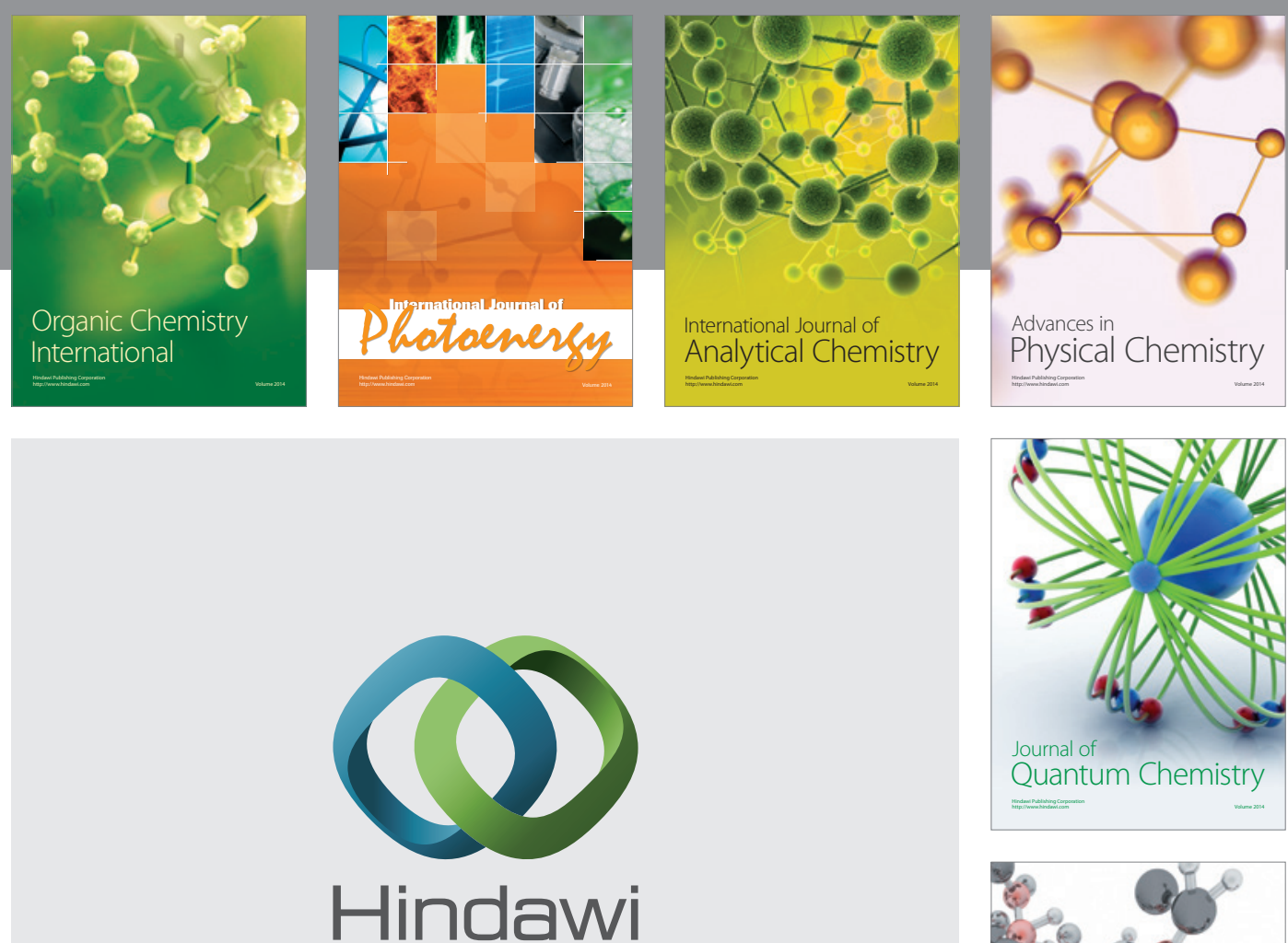

Submit your manuscripts at

http://www.hindawi.com

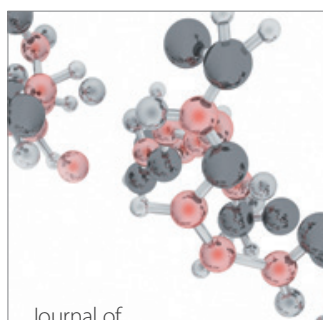

Analytical Methods

in Chemistry

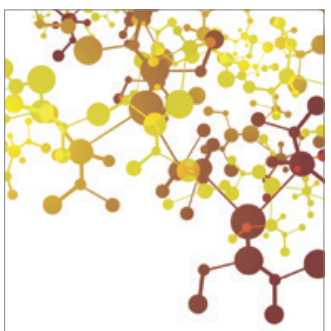

Journal of

Applied Chemistry

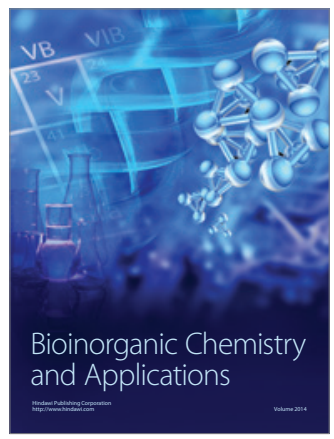

Inorganic Chemistry
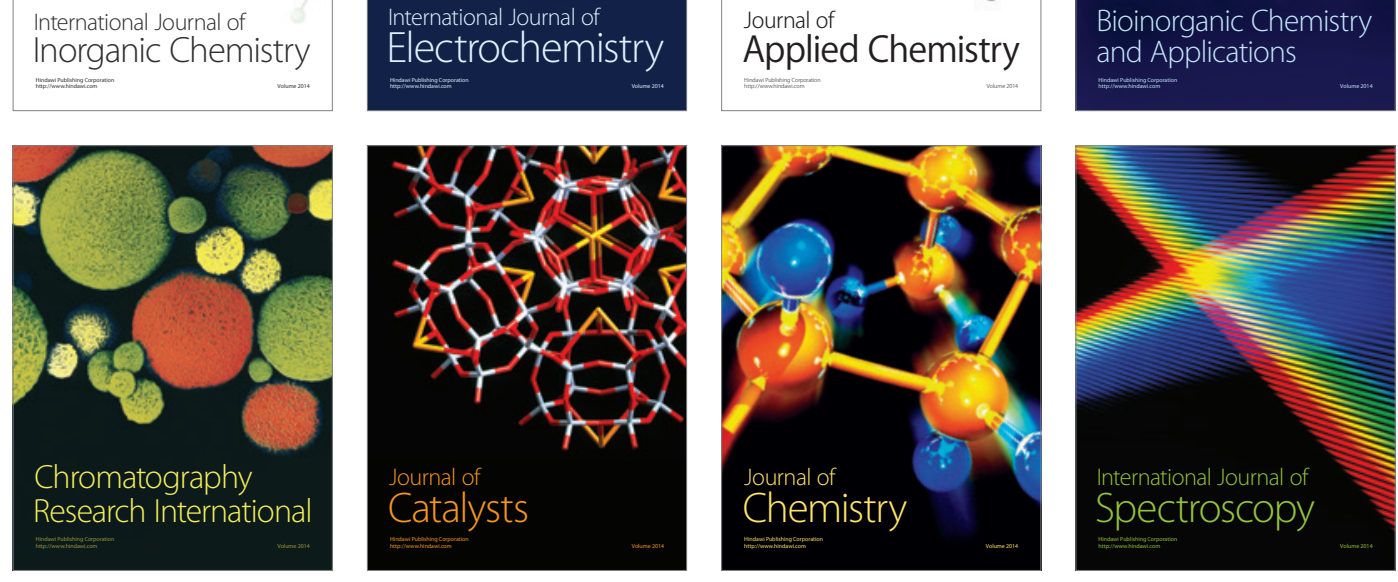